ISSN (print): 0853-8301; ISSN (online): 2745-777X Available online at https://ejournal.unib.ac.id/index.php/triadik DOI: https://doi.org/10.33369/triadik.v20i1.16465 page: $10-19$

\title{
PENGARUH LAYANAN KONSELING KELOMPOK DENGAN TEKNIK SELF-TALK TERHADAP KEJENUHAN (BURNOUT) BELAJAR SISWA XI MIPA F DI SMA NEGERI 2 KOTA BENGKULU
}

\author{
1Uni Nopriani, ${ }^{1}$ Syahriman, ${ }^{3}$ Anna Ayu Herawati \\ 1,2,3Universitas Bengkulu
}

Korespondensi: uninopriani26@gmail.com

\begin{abstract}
Abstrak
Penelitian ini dilatarbelakangi oleh adanya kejenuhan belajar yang mengakibatkan masalah untuk siswa dalam belajar. Penelitian ini bertujuan untuk mendeskripsikan pengaruh layanan konseling kelompok dengan teknik self-talk terhadap kejenuhan (burnout) belajar siswa XI MIPA F di SMA Negeri 2 Kota Bengkulu. Metode penelitian ini menggunakan ekperimen dengan one-group pretest-posttest design. Siswa kelas XI MIPA F berjumlah 35 orang sebagai populasi dengan teknik purposive sampling diambil sampel 6 orang. Teknik pengumpulan data mengunakan kuisoner skala Likert. Analisis data menggunakan Uji T (paired sample test). Hasil yang diperoleh dalam penelitian ini menunjukkan adanya penurunan kejenuhan belajar siswa setelah diberikan konseling kelompok dengan teknik self-talk sebagai perlakuan. Hal ini ditunjukkan dengan nilai $\mathrm{T}=11.400 \mathrm{dan}$ sig (2-tailed) 0.000 yang berarti $0,000<0,05$ sehingga $\mathrm{H}_{0}$ ditolak dan $\mathrm{H}_{\mathrm{a}}$ diterima. Artinya ada pengaruh layanan konseling kelompok dengan teknik self-talk terhadap kejenuhan (burnout) belajar siswa XI MIPA F di SMA Negeri 2 Kota Bengkulu.
\end{abstract}

Kata kunci: kejenuhan belajar, konseling kelompok, teknik self-talk

\begin{abstract}
This research is motivated by the existence of learning burnout which causes problems for students in learning. This study aims to describe the effect of group counseling services using self-talk techniques on learning burnout of XI MIPA F students at SMA Negeri 2 Bengkulu City. This research method uses an experiment with a one-group pretest-posttest design. There are 35 students of class XI MIPA F as a population with a purposive sampling technique taken as a sample of 6 people. The data collection technique used a Likert scale questionnaire. Data analysis used a T-test (paired sample test). The results obtained in this study indicate a decrease in student learning burnout after being given group counseling with self-talk as a treatment. This is indicated by the value of $T=11,400$ and sig (2-tailed) 0,000, which means 0,000 $<0.05$ so that $H_{0}$ is rejected and $H_{a}$ is accepted. This means that there is an effect of group counseling services with self-talk techniques on learning burnout of XI MIPA F students at SMA Negeri 2 Bengkulu City.
\end{abstract}

Keywords: burnout learning, group counseling, self-talk technique 


\section{Pendahuluan}

Kegiatan pembelajaran dan belajar adalah kegiatan pokok artinya berhasil tidaknya tujuan pendidikan bergantung pada proses pembelajaran dan belajar siswa sebagai peserta didik. Menurut Sugihartono (dalam Ningsih, 2016:51) pembelajaran merupakan kegiatan yang dilakukan untuk menciptakan suasana atau memberikan pelayanan agar siswa belajar. Sedangkan menurut Syah (dalam Aryana, 2019:3) belajar adalah kegiatan berproses dan merupakan unsur yang sangat fundamental dalam penyelenggaraan setiap jenis dan jenjang pendidikan. Proses pembelajaran dan belajar yang ada di sekolah dinyatakan berhasil merujuk implementasinya pada hasil belajar.

Menurut Hamalik (dalam Wardani, 2019:2) hasil belajar ialah sebagai terjadinya perubahan tingkah laku pada diri seseorang yang dapat diamati dan diukur bentuk pengetahuan, sikap dan keterampilan. Perubahan tersebut dapat diartikan sebagai terjadinya peningkatan dan pengembangan yang lebih baik yaitu sebelum yang tidak tahu menjadi tahu. Untuk mendapatkan hasil belajar yang baik dan maksimal seringkali siswa mendapatkan tuntutan dan harapan yang harus dipenuhi, baik dari lingkungan sekolah maupun keluarga maka dibutuhkan kesiapan fisik dan psikologis agar belajar menjadi menyenangkan dan tidak menimbulkan stres akademik. Stres akademik adalah tekanan akibat persepsi subjektif terhadap suatu kondisi akademik, tekanan ini melahirkan respon yang dialami siswa berupa reaksi fisik, perilaku, pikiran, dan emosi negatif yang muncul akibat adanya tuntutan sekolah atau akademik (Barseli \& Ifdil, 2017:144). Jika stres akademik berkepanjangan maka siswa akan mengalami kelelahan secara fisik dan psikologis hingga mengalami kejenuhan belajar.

Kejenuhan belajar merupakan suatu keadaan yang dirasakan individu berupa rasa bosan dan rasa lelah fisik hingga tidak bersemangat dalam kegiatan belajar. Seperti pendapat Syah (dalam Ningsih, 2016:52) kejenuhan belajar dapat terjadi karena proses belajar siswa telah sampai pada batas kemampuan jasmaniah karena bosan (boring) dan keletihan (fatigue). Rebet (dalam Magrur et al., 2020:118) menyatakan bahwa kejenuhan belajar merupakan lama waktu yang digunakan pada anak-anak sedang belajar, tetapi tidak mendatangkan hasil yang dicapai. Siswa yang mengalami kejenuhan belajar tidak dapat mengelolah cara berpikir dan cara pemahamannya terhadap pembelajaran sehingga proses pengetahuannya akan terganggu dan tidak ada kemajuan. Kejenuhan belajar yang tinggi dapat mengganggu aktivitas pembelajaran dan belajar siswa sebagai peserta didik hingga tidak berjalan efektif.

Berdasarkan pengamatan dalam kegiatan magang II selama 2 bulan yaitu tanggal 9 September hingga 9 November 2019 di SMAN 2 Kota Bengkulu, kejenuhan belajar merupakan salah satu permasalahan yang ditemui. Hal ini terlihat beberapa siswa tidak bergairah atau bersemangat dalam belajar dan pelajaran tertentu, terlihat lesu pada pelajaran siang hingga sore, kurang berkonsentrasi atau kurang fokus terhadap proses pembelajaran dan belajar, serta terlihat tidak nyaman belajar dan berada di dalam kelas. Kemudian, beberapa siswa tak jarang mereka melakukan perilaku menyimpang seperti membolos dari kelas hingga mencari alasan agar dapat keluar dari sekolah untuk menghindari kegiatan belajar. Selain itu, pada saat melaksanakan layanan secara klasikal siswa meminta diberi 
aktivitas permainan didalam kelas. Pada saat kegiatan kelompok juga, beberapa siswa menyatakan merasa lelah fisik akibat kekurangan waktu senggang karena disita oleh kegiatan sekolah dari pagi hingga sore kemudian ada yang melanjutikan kegiatan ekstrakurikuler dan kegiatan Bimbingan Belajar (BIMBEL) di sekolah dan luar sekolah.

Kondisi kejenuhan belajar pada siswa harus segera ditangani, sebab jika berlanjut akan berdampak pada kemunduran dalam hal mencapai tujuan belajar dan dapat berdampak juga pada pendidikan selanjutnya yaitu jenjang perguruan tinggi ataupun karir. Kejenuhan belajar merupakan salah satu masalah pada bidang belajar sehingga diperlukan perlakuan yang lebih tepat salah satunya melalui layanan bimbingan dan konseling di sekolah.

Dalam penelitian ini peneliti menggunakan layanan konseling kelompok yang merupakan salah satu strategi didalam layanan responsif. Konseling kelompok adalah upaya pengentasan masalah klien salah satu anggota kelompok melalui dinamika kelompok. Hasnida (2016:25) menyatakan bahwa konseling kelompok adalah upaya bantuan yang bersifat pencegahan dan pengembangan kemampuan pribadi sebagai pemecahan masalah secara kelompok atau bersama-sama dari seorang konselor kepada klien. Berdasarkan penjelasan di atas, konseling kelompok bertujuan untuk mengembangkan keterampilan siswa (konseli) agar siswa dapat mengubah penyesuaian tingkah laku yang salah, belajar membuat keputusan dan mencegah timbulnya masalah, sehingga konseling kelompok dapat diterapkan untuk pengentasan masalah klien khususnya pada masalah kejenuhan belajar siswa.

Teknik self-talk adalah teknik berdialog atau berbicara pada diri sendiri tepatnya pada pikiran-pikiran. Seligman \& Reichenberg (dalam Erford, 2015:223) menyatakan bahwa teknik self-talk sebagai sebuah pep talk (pembicaraan yang dimaksud untuk membangkitkan keberanian dan antusiasme) positif yang diberikan seseorang kepada dirinya sendiri setiap hari. Dalam penggunaan teknik self-talk yaitu seseorang dapat menyebutkan frasa suportif yang sangat membantu ketika individu (siswa) dihadapkan dengan suatu masalah.

Maka dari itu, peneliti menggunakan layanan konseling kelompok dengan teknik self-talk. Selain itu dikarenakan kejenuhan belajar siswa difaktori oleh lamanya waktu belajar, tuntutan tugas hingga siswa merasa bosan dan letih. Hal ini didorong oleh pikiran negatif sehingga mengakibatkan masalah untuk siswa dalam proses belajar. Layanan konseling kelompok adalah kegiatan yang memanfaatkan dinamika kelompok untuk membantu mengentaskan masalah dan teknik self-talk termasuk kedalam pendekatan kognitif perilaku yang artinya adalah berbicara pada diri sendiri tepatnya pada pikiran-pikiran maka dari itu layanan konseling kelompok teknik self-talk dianggap peneliti efektif untuk digunakan pada kejenuhan belajar siswa.

Mengacu pada uraian latar belakang tersebut maka peneliti tertarik untuk melakukan layanan konseling kelompok dalam sebuah penelitian berjudul "Pengaruh Layanan Konseling Kelompok dengan Teknik Self-Talk terhadap Kejenuhan (Burnout) Belajar Siswa XI MIPA F di SMA Negeri 2 Kota Bengkulu".

\section{Rumusan Masalah}


Berdasarkan permasalahan di atas, maka rumusan masalah dalam penelitian ini adalah bagaimana tingkat kejenuhan belajar siswa kelas XI MIPA F SMA Negeri 2 Kota Bengkulu sebelum dilakukan pemberian layanan konseling kelompok teknik self-talk, bagaimana tingkat kejenuhan belajar siswa kelas XI MIPA F SMA Negeri 2 Kota Bengkulu setelah dilakukan pemberian layanan konseling kelompok teknik self-talk, bagaimana pengaruh konseling kelompok teknik self-talk terhadap kejenuhan belajar siswa kelas XI MIPA F SMA Negeri 2 Kota Bengkulu.

Kerangka Berpikir

Adapun kerangka pikir pada penelitian ini adalah:

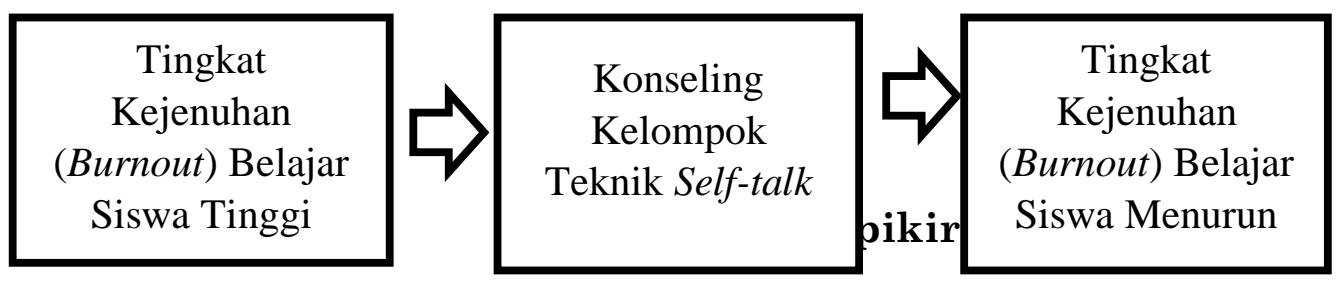

Penjelasan kerangka berpikir di atas yaitu siswa yang menjadi subjek penelitian ini adalah siswa yang memiliki tingkat kejenuhan (burnout) belajar tertinggi diberikan perlakuan (perlakuan) sebagai bentuk bantuan berupa layanan konseling kelompok dengan teknik self-talk diharapkan tingkat kejenuhan (burnout) belajar siswa dapat menurun.

\section{Metode Penelitian}

Desain penelitian ini adalah eksperimen metode kuantitatif dengan pola one-group pretest-posttest design. Penelitian ini memberikan perlakuan berupa layanan konseling kelompok dengan teknik self-talk terhadap kejenuhan (burnout) belajar siswa. Jadi, subjek dilakukan dua kali pengukuran (uji dua sampel satu variabel) yaitu pengukuran pertama (pretest) dan pengukuran kedua (post-test) masing-masing untuk mengukur tingkat kejenuhan belajar siswa sebelum dan setelah diberikan perlakuan.

Populasi pada penelitian ini adalah kelas XI MIPA F di SMA Negeri 2 Kota Bengkulu yang berjumlah 35 orang siswa. Sampel merupakan bagian dari populasi. Sampel penelitian ini berjumlah 6 orang siswa yang memiliki skor kejenuhan belajar tertinggi di atas 140 pada pre-test dan memenuhi ciri serta aspek kejenuhan belajar. Teknik pengambilan subjek penelitian adalah purposive sampling yaitu berdasarkan pada kriteria atau ciri-ciri tertentu berkaitan dengan kejenuhan belajar berupa siswa yang mengalami kejenuhan belajar tinggi seperti tidak bergairah atau bersemangat untuk belajar, lesu, malas, kurang konsentrasi, menghindar dari proses belajar dan tidak nyaman dalam kelas atau melakukan tugas-tugas.

Teknik Pengumpulan data menggunakan kuesioner (angket) model skala Likert dengan alternatif jawaban (SS) Sangat Sesuai, (S) Sesuai, (TS) Tidak Sesuai dan (STS) Sangat Tidak Sesuai. Kuisioner merupakan instrument (alat) untuk mendapatkan data siswa melalui butir-butir pertanyaan atau pernyataan yang harus dijawab oleh siswa. Kuisoner ini digunakan untuk mengukur tingkat kejenuhan (burnout) belajar siswa di kelas XI MIPA F SMA Negeri 2 Kota Bengkulu dan penggunaan model skala Likert dikarenakan dapat mengukur sikap responden dan juga mempunyai frekuensi atau skor jawaban yang rinci dari sangat positif sampai sangat negatif. 
Pengujian validitas menggunakan validitas isi yaitu melibatkan ahli (expert judgment) untuk mengevaluasi keterwakilan seluruh aspek pengukuran dan uji coba kuisoner ke kelas bukan populasi. Kuisoner yang telah divalidasi ahli selanjutnya di uji coba kelas bukan kelas populasi/sampel selanjutnya diolah dengan perhitungan statistik program aplikasi SPSS 24.0., digunakan tabel $\mathrm{r}$ (product moment) untuk menentukan kategori valid berdasarkan $\mathrm{n}$ dan alpha $5 \%$ (Umar, 2013:174). Berdasarkan uji validitas ahli semula berjumlah 92 butir item menjadi 85 butir item, selanjutnya uji coba semula ada 85 butir menjadi 53 butir item yang valid dan digunakan untuk butir soal pre-test dan post-test. Uji reliabilitas dilakukan berkenaan dengan derajat konsistensi alat ukur dengan bantuan perhitungan statistik program aplikasi SPSS versi 24.0 menggunakan rumus Crounbach's Alpha karena bentuk skala lebih dari dua yaitu 1-4 dengan syarat apabila nilai alpha lebih besar dari 0,7 maka reliabel (Umar, 2013:174). Nilai alpha penelitian ini 0,942 yang berarti kuisoner reliabel.

Hasil uji normalitas menentukan penggunaan metode uji statistik yaitu jika pada penelitian ini persyaratan normalitas terpenuhi yaitu data berdistribusi normal maka analisis menggunakan metode parametrik namun jika sebaliknya maka menggunakan metode nonparametrik. Pada penelitian ini digunakan rumus uji Kolmogorov-Smirnov dengan bantuan program aplikasi SPPS 24.0 menggunakan taraf signifikansi 0,05. Data dinyatakan berdistribusi normal jika Kolmogorov hitung $<$ Kolmogorov Tabel dan nilai sig $>0,05$. Pada penelitian ini $\mathrm{K}_{\text {tabel }}$ pada $\mathrm{N}=35$ yaitu 0,224 dan hasil uji normalitas menunjukkan $K_{\text {hitung }}=0,109$ maka 0,109 $<0,224$, kemudian pada nilai signifikan atau sig yaitu $0,200>0,05$ yang artinya data berdistribusi normal sehingga metode uji statistik penelitian ini menggunakan metode uji statistik parametrik.

\section{Hasil dan Pembahasan}

Dalam menentukan kategori perolehan skor siswa yang mengalami kejenuhan belajar, diawali dengan mencari mean dan standard deviasi. Mean penelitian ini sebesar 132,5 dan standar deviasi sebesar 26,5 dengan skor minimum 53 dan skor maksimum sebesar 212 menggunakan 5 kategori yaitu sangat tinggi, tinggi, sedang, rendah dan sangat rendah. Berdasarkan perhitungan didapatkan rentang katergori pada interval dan hasil pre-test ditunjukkan pada tabel:

Tabel 1.

Frekuensi Pre-test Kejenuhan Belajar Siswa

\begin{tabular}{lclc}
\hline \multicolumn{1}{c}{ Interval } & Frekuensi & \multicolumn{1}{c}{ Kategori } & Persentase \\
\hline$>146$ & 3 & Sangat Tinggi & $9 \%$ \\
\hline $133-145$ & 11 & Tinggi & $31 \%$ \\
\hline $120-132$ & 13 & Sedang & $37 \%$ \\
\hline $94-119$ & 7 & Rendah & $20 \%$ \\
\hline$<93$ & 1 & Sangat Rendah & $3 \%$ \\
\hline Total & $\mathbf{3 5}$ & & \\
\hline
\end{tabular}

Berdasarkan hasil tersebut, dapat diketahui bahwa siswa yang mengalami kejenuhan belajar dengan kategori sangat tinggi (>146) sebanyak 3 orang dengan persentase $9 \%$, siswa dengan kategori tinggi (133-145) sebanyak 11 orang siswa dengan persentase $31 \%$, siswa dengan kategori 
sedang (120-132) sebanyak 13 orang dengan persentase $37 \%$, siswa dengan kategori rendah (94-119) sebanyak 7 orang dengan persentase $20 \%$, siswa dengan kategori sangat rendah $(<93)$ hanya 1 orang dengan persentase $3 \%$. Perlakuan diberikan pada sampel berjumlah 6 orang sebanyak 6 kali pertemuan, siswa sampel penelitian ini diambil yang memiliki skor tertinggi kejenuhan belajar dari hasil pre-test. Kemudian setelah pemberian perlakuan layanan konseling kelompok teknik self-talk selanjutnya adanya post-test yaitu kuesoner kejenuhan belajar siswa diberikan kembali kepada 6 siswa sampel. Angket yang diberikan untuk post-test sama dengan angket yang diberikan pada saat pre-test.

Tabel 2.

Frekuensi Post-test Tingkat Kejenuhan Belajar Siswa

\begin{tabular}{lclc}
\hline \multicolumn{1}{c}{ Interval } & Frekuensi & \multicolumn{1}{c}{ Kategori } & Persentase \\
\hline$>146$ & 0 & Sangat Tinggi & $0 \%$ \\
\hline $133-145$ & 0 & Tinggi & $0 \%$ \\
\hline $120-132$ & 2 & Sedang & $33 \%$ \\
\hline $94-119$ & 4 & Rendah & $67 \%$ \\
\hline$<93$ & 0 & Sangat Rendah & $0 \%$ \\
\hline Total & $\mathbf{6}$ & &
\end{tabular}

Berdasarkan tabel 2 di atas, Setelah diberikan konseling kelompok dengan teknik self-talk menunjukkan hasil post-test yaitu bahwa siswa dengan kategori sedang berjumlah 2 orang dengan persentase $33 \%$, siswa dengan kategori rendah berjumlah 4 orang dengan persentase $67 \%$. Hasil tersebut menyatakan bahawa sudah tidak ada lagi siswa yang masuk ke dalam kategori sangat tinggi dan tinggi, sehingga dapat disimpulkan bahwa hasil post-test, 6 orang siswa kelas XI MIPA F setelah diberikan perlakuan mengalami penurunan tingkat kejenuhan belajar. Berikut perbandingan skor dan mean 6 orang sampel yang memiliki skor tertinggi saat pre-test dan post-test setelah diberikan perlakuan dapat dilihat pada tabel di bawah ini :

Tabel 3.

Perbandingan Skor Pre-test dan Post-test Tingkat Kejenuhan Belajar

\begin{tabular}{|c|c|c|c|c|c|c|}
\hline NO & $\begin{array}{c}\text { Nam } \\
\mathbf{a}\end{array}$ & $\begin{array}{c}\text { Skor } \\
\text { Pre- } \\
\text { test }\end{array}$ & Kategori & $\begin{array}{c}\text { Skor } \\
\text { Post- } \\
\text { test }\end{array}$ & $\begin{array}{c}\text { Katego } \\
\text { ri }\end{array}$ & $\begin{array}{c}\text { Skor } \\
\text { Penurun } \\
\text { an }\end{array}$ \\
\hline 1 & LA & 148 & $\begin{array}{l}\text { Sangat } \\
\text { Tinggi }\end{array}$ & 109 & Rendah & 39 \\
\hline 2 & SH & 148 & $\begin{array}{l}\text { Sangat } \\
\text { Tinggi }\end{array}$ & 121 & Sedang & 27 \\
\hline 3 & UF & 140 & Tinggi & 110 & Rendah & 30 \\
\hline 4 & MM & 145 & Tinggi & 107 & Rendah & 38 \\
\hline 5 & NS & 146 & $\begin{array}{l}\text { Sangat } \\
\text { Tinggi }\end{array}$ & 109 & Rendah & 37 \\
\hline 6 & $\mathrm{AS}$ & 142 & Tinggi & 120 & Sedang & 22 \\
\hline & Jumla & 869 & & 676 & & \\
\hline & $\operatorname{Max}$ & 148 & & 121 & & \\
\hline & Min & 140 & & 107 & & \\
\hline & Mean & 144,83 & & 112,67 & & \\
\hline
\end{tabular}


Pada tabel 3 di atas terlihat skor penurunan siswa yang berbeda-beda hal ini terjadi karena setiap siswa memiliki kemampuan berbeda-beda untuk menerima sesuatu hal, ini terlihat hasil lembar penilaian segera (laiseg) dan terlihat pada perubahan setiap pertemuan. Penerapan layanan konseling kelompok dengan teknik self-talk yang membahas masalah masing-masing anggota kelompok siswa sesuai dengan keadaan yang ia rasakan mengenai kejenuhan belajar dengan berpacu pada hasil pre-test.

Pada proses pelaksanaan konseling kelompok sebanyak 6 pertemuan ini terlihat siswa akrab, terbuka menyampaikan permasalahan dan pendapatnya yang menggunakan kalimat berasal dari pikiran yang luas (pikiran positif) dengan tujuan untuk saling membantu. Artinya bahwa siswa telah memahami dan mulai menerapkan teknik self-talk. Berdasarkan hasil perbandingan skor pre-test dan post-test di atas menunjukkan ada penurunan skor yang signifikan dari tingkat kejenuhan belajar siswa setelah diberikan perlakuan dan mean (rata-rata) yang awalnya 144,83 menjadi 112,67. Kemudian juga dibuktikan dari hasil uji hipotesis.

Adapun hasil uji hipotesis yang diperoleh dengan menggunakan SPSS versi 24.0 sebagai berikut :

Tabel 4.

Hasil Uji T-Test

\begin{tabular}{|c|c|c|c|c|c|c|c|c|c|}
\hline \multicolumn{10}{|c|}{ Paired Samples Test } \\
\hline & & \multicolumn{5}{|c|}{ Paired Differences } & \multirow[b]{2}{*}{$\mathrm{T}$} & \multirow[b]{2}{*}{ Df } & \multirow[b]{2}{*}{$\begin{array}{l}\text { Sig. } \\
(2- \\
\text { taile } \\
\text { d) }\end{array}$} \\
\hline & & Mean & $\begin{array}{c}\text { Std. } \\
\text { Devia } \\
\text { tion }\end{array}$ & $\begin{array}{c}\text { Std. } \\
\text { Erro } \\
\text { r } \\
\text { Mea } \\
\text { n }\end{array}$ & $\begin{array}{r}9 \\
\text { Conf } \\
\text { Inte } \\
\text { the Di } \\
\text { Lower }\end{array}$ & $\begin{array}{l}\% \\
\text { dence } \\
\text { val of } \\
\text { erence } \\
\text { Upper }\end{array}$ & & & \\
\hline Pair 1 & $\begin{array}{c}\text { Pretest } \\
- \\
\text { Posttes } \\
\text { t }\end{array}$ & $\begin{array}{c}32.16 \\
7\end{array}$ & 6.911 & $\begin{array}{c}2.82 \\
2\end{array}$ & $\begin{array}{c}24.91 \\
4\end{array}$ & $\begin{array}{c}39.42 \\
0\end{array}$ & $\begin{array}{c}11.40 \\
0\end{array}$ & 5 & .000 \\
\hline
\end{tabular}

Berdasarkan hasil uji hipotesis ditunjukkan bahwa terjadi perubahan tingkat kejenuhan belajar siswa pada pre-test dan post-test melalui analisis $t$ test sampel related (berpasangan/paired) yang menunjukkan nilai sig (2tailed) sebesar 0,000 artinya 0,000 $<0,05(\mathrm{p}<0,05)$. Hasil uji hipotesis ini signifikan karena jika Sig. (2-tailed) $<0,05$ maka berdasarkan kriteria penerimaan atau penolakan hipotesis $\mathrm{H}_{0}$ ditolak dan $\mathrm{H}_{a}$ diterima. Sehingga terdapat pengaruh layanan konseling kelompok dengan teknik self-talk untuk menurunkan tingkat kejenuhan belajar siswa kelas XI MIPA F di SMA Negeri 2 Kota Bengkulu.

Hasil penelitian ini selaras dengan penelitian terdahulu yang dilakukan (Anggreini et al., 2019), (Magrur et al., 2020), (Khaira, 2018) bahwa penggunaan pendekatan REBT, penggunaan teknik seperti teknik selfinstruction dengan pengaturan kelompok seperti konseling kelompok menghasilkan perbedaan skor sebelum dan sesudah perlakuan hingga dinyatakan efektif untuk mengurangi kejenuhan atau kelelahan belajar siswa. Sehingga disimpulkan bahwa ada pengaruh yang signifikan dari penerapan perlakuan layanan konseling kelompok teknik self-talk terhadap tingkat kejenuhan belajar siswa. Maka penerapan layanan konseling kelompok dengan teknik self-talk efektif dalam menurunkan tingkat 
kejenuhan (burnout) belajar siswa kelas XI MIPA F di SMA Negeri 2 Kota Bengkulu.

Kejenuhan belajar ialah rasa lelah dan bosan yang dialami seseorang karena tuntutan akademik. Kejenuhan belajar juga merupakan salah satu permasalahan yang sering dialami oleh siswa. Sesuai dengan pendapat Maslach (dalam Sholawati, 2016:19) yaitu burnout (kejenuhan) sebagai keadaan kelelahan fisik, emosional dan mental. Kemudian menurut Hakim (dalam Fatmawati, 2018:706) kejenuhan belajar diartikan sebagai suatu kondisi mental seseorang saat mengalami rasa bosan dan lelah yang amat sangat sehingga mengakibatkan timbulnya rasa enggan, lesu, tidak bersemangat melakukan aktivitas belajar. Berdasarkan observasi sebelumnya pada saat magang dan informasi dari guru BK di sekolah, beberapa siswa mengalami lesu, tidak bersemangat saat belajar, dan mengeluh saat kepada guru BK saat pelajaran BK.

Aktivitas yang dijalani oleh peserta didik banyak dihabiskannya di sekolah untuk belajar, berdasarkan informasi dari guru BK dan Waka HUMAS bahwa di SMA Negeri 2 Kota Bengkulu menerapkan kegiatan akademik dari pagi hingga sore hari, tidak ada bedanya dengan keadaan pandemi saat ini meskipun via daring siswa memiliki aktivitas belajar lebih padat. Siswa dituntut sekolah seperti biasa dan diberikan tugas pada setiap waktunya. Beberapa siswa berpendapat bahwa ini menjadi sumber jenuhnya dalam belajar, selaras dengan pendapat Maslach dan Leiter (dalam Wahyuni, 2018:155) bahwa kejenuhan belajar terjadi karena beberapa faktor seperti kurangnya penghargaan, kurangnya pengawasan, beban tugas akademis yang berlebihan, cara atau metode belajar yang tidak bervariasi konflik nilai, kurang keadilan dapat membuat seseorang mengalami kejenuhan. Selain itu menurut Agustin (dalam Murtana, 2014:3) faktor yang menyebabkan kejenuhan belajar adalah karakteristik pribadi (personal characteristic), faktor dukungan sosial (social support), faktor beban akademis yang berlebihan (Courseload). Sehingga dapat disimpulkan bahwa kemampuan diri, kondisi internal dalam diri, kepribadian atau karakteristik, beban dibidang akademik, dukungan sosial dan situasi lingkungan di sekolah menjadi sumber kejenuhan belajar pada siswa.

Alasan peneliti menggunakan teknik self-talk sebagai perlakuan karena berfokus pada pikiran-pikiran yang mengubah perilaku, dengan teknik ini siswa dapat memberikan frasa suportif untuk dirinya sendiri guna membangkitkan keberanian dan antusiasme serta sangat membantu siswa jika dihadapkan dengan suatu masalah. Jadi, teknik self-talk ini digunakan untuk anggota kelompok dalam mengubah perilaku tidak baiknya secara perlahan melalui pola pikir yang diverbalisasikan. Ketika siswa merasakan bosan dan kelelahan secara fisik maupun psikologis, stres akademik atau lainnya, kemudian dirinya mampu mengendalikan pikiran negatifnya sehingga membantu siswa untuk berpikir positif sebagai kualitas kepribadian, berpikir positif terhadap lingkungan artinya dapat memperbaiki persepsi siswa terhadap faktor dukungan sosial serta siswa dapat menerima dan tidak menganggap setiap tugas yang diberi sebagai beban akademis.

Hambatan

Kondisi pandemi yang dialami saat ini cukup menyulitkan peneliti untuk melaksanakan penelitian. Peneliti harus menyesuaikan dengan keadaan sekolah online siswa dan juga mengutamakan protokol kesehatan 
dan meminimalisir kerumunan orang. Proses adminitrasi izin penelitian yang menghabiskan hampir 2 minggu sehingga mengurangi perencanaan waktu pelaksanaan penelitian.

\section{Simpulan}

Tingkat kejenuhan belajar siswa sebelum diberikan layanan konseling kelompok teknik self-talk dari 6 orang siswa pada kategori sangat tinggi berjumlah 3 orang dengan persentase 50\% dan kategori tinggi berjumlah 3 orang dengan persentase 50\%. Hasil rata-rata tingkat kejenuhan belajar siswa sebelum diberikan layanan konseling kelompok teknik self-talk dengan nilai 144,83 masuk dalam katagori tinggi.

Tingkat kejenuhan belajar siswa setelah diberikan layanan konseling kelompok teknik self-talk dari 6 orang siswa terdapat penurunan skor yaitu diketahui 2 orang siswa dengan persentase 33\% pada kategori sedang dan 4 orang lainnya dengan persentase $67 \%$ berada pada katergori rendah. Hasil rata-rata tingkat kejenuhan belajar siswa setelah diberikan layanan konseling kelompok teknik self-talk dengan nilai 112,67 tergolong dalam kategori rendah.

Berdasarkan hasil analisis uji t yang telah dilakukan, diketahui bahwa terdapat perbedaan sebelum dan sesudah diberikan perlakuan (perlakuan) konseling kelompok dengan teknik self-talk terhadap siswa yang mengalami kejenuhan belajar. Hasil analisis uji t tersebut menunjukkan bahwa Sig. (2tailed) sebesar 0,000 yang berarti nilai signifikan $0.000<0,05$ sehingga $\mathrm{H} 0$ ditolak dan Ha diterima. Berdasarkan hasil tersebut disimpulkan bahwa ada pengaruh layanan konseling kelompok dengan teknik self-talk untuk menurunkan kejenuhan belajar siswa kelas XI MIPA F di SMA Negeri 2 Kota Bengkulu.

Selanjutnya, saran yang dapat diberikan peneliti yaitu bagi siswa diharapkan agar konsisten menerapkan teknik self-talk agar tetap terus meningkatkan kemampuan mengelola pernyataan/statement/persepsi negatif yang muncul menjadi positif dan mengelola pola pikir/mindset positif sehingga menjadi karakter diri yang dapat berpikir positif terhadap kondisi dan masalah apapun yang dihadapi terkhusus kejenuhan belajar, sebagai masukan terhadap pihak sekolah perlu lebih memperhatikan, bekerjasama dan memfasilitasi seluruh warga sekolah terutama guru BK untuk memberikan layanan dan membantu siswa agar dapat menghadapi masalahmaslah akademiknya dengan baik dan dapat mencapai tujuan pendidikan. Bagi peneliti selanjutnya diharapkan dapat meningkatkan kemampuan serta lebih kreatif dan inovatif dalam pemberian layanan dan perlakuan untuk membantu siswa.

\section{Daftar Pustaka}

Anggreini, C., Daharnis, D., \& Karneli, Y. (2019). The Effectiveness of Group Rational Emotive Behavior Therapy to Reduce Student Learning Burnout. International Journal of Research in Counseling and Education, 3(2), 109. https://doi.org/10.24036/00103za0002

Aryana, I. M. P. (2019). Model Pembelajaran Kooperatif Tipe Group Investigation Untuk Meningkatkan Motivasi Belajar Dan Hasil Belajar Siswa. Adi Widya: Jurnal Pendidikan Dasar, 4(1), 61. https://doi.org/10.25078/aw.v4i1.931 
Barseli, M., \& Ifdil, I. (2017). Konsep Stres Akademik Siswa. Jurnal Konseling Dan Pendidikan, 5(3), 143. https://doi.org/10.29210/119800

Erford, B. T. (2015). 40 Teknik yang Harus Diketahui Setiap Konselor. Yogyakarta: Pustaka Belajar

Fatmawati. (2018). Hubungan Antara Kejenuhan Belajar Dengan Stres Akademik (Pada Siswa-siswi Full Day School di SMPN 2 Samarinda). Psikoborneo, 6(4), 712.

Hasnida, N. L. L. (2016). Konseling Kelompok. Jakarta: Kencana

Khaira, N. A. (2018). Penerapan Teknik Self Instruction Untuk Mengurangi Kejenuhan Belajar Siswa. Jurnal Pencerahan, 4(1), 13-30.

Magrur, R. Y., Siregar, N. R., \& Silondae, D. P. (2020). Pengaruh Layanan Konseling Kelompok Terhadap Kejenuhan Belajar Siswa. Jurnal Ilmiah Bening: Belajar Bimbingan Dan Konseling, 4(1), 117-124. https://doi.org/10.36709/bening.v4i1.10496

Murtana, A. (2014). Hubungan Antara Hargga Diri Dan Interaksi Teman Sebaya Dengan Stres Belajar. 1-20. http://eprints.ums.ac.id/39224/

Ningsih, F. (2016). Efektifitas Teknik Relaksasi Untuk Mengurangi Kejenuhan. E-Journal Bimbingan Dan Konseling Edisi 7 Tahun Ke-5, 7(5), 50-59.

Sholawati, S. A. (2016). Pengaruh Teknik Jigsaw Dalam Pembelajaran Ilmu Pengetahuan Sosial Untuk Menurunkan Burnout Belajar Pada Siswa SMP Islam Ngoro Jombang. Undergraduate Thesis, 1 -28. http://digilib.uinsby.ac.id/13182/

Umar, H. (2013). Metode Penelitian untuk Skripsi dan Tesis Bisnis Edisi Kedua. Jakarta: Rajawali Pers

Wahyuni, E. D. (2018). Faktor-Faktor Penyebab Tingkat Kejenuhan Belajar Pendidikan Agama Islam (Pai) Pada Jurusan Pgsd Di Universitas Islam Balitar. Konstruktivisme: Jurnal Pendidikan \& Pembelajaran, 10(2), 154162. https://doi.org/10.30957/konstruk.v10i2.509

Wardani, L. (2019). Penggunaan Media Audio Visual Untuk Meningkatkan Hasil Belajar Seni Budaya Dan Keterampilan Siswa Kelas IV Sekolah Dasar Negeri 004 Rambah Samo. Indonesian Journal of Basic Education, 2(1), 1-4. https://stkiprokania.ac.id/ejurnal/index.php/IJOBE/article/view/205 